$\xi=-1$

\title{
Anaerobic Reactor for Indonesian Tofu Wastewater Treatment
}

\author{
Sanggono Adisasmito ${ }^{1 *}$, Carolus Borromeus Rasrendra ${ }^{1}$, Hengky Chandra $^{1}$, and \\ Mohammad Adimas Gunartono \\ ${ }^{1}$ Chemical Engineering Department, Institut Teknologi Bandung, Bandung 40132, Indonesia \\ *Corresponding author E-mail: sanggono@che.itb.ac.id
}

\begin{abstract}
An Upflow Anaerobic Sludge Blanket (UASB) reactor was used to process liquid wastes from a tofu industry with COD (Chemical Oxygen Demand) $7619 \mathrm{mg} / \mathrm{L}, \mathrm{pH} 4$, and TSS (Total Suspended Solid) $1035 \mathrm{mg} / \mathrm{L}$. This work is part of efforts to clean Citarum River in West Java, Indonesia, named as Citarum Harum national program. The liquid Hydraulic Retention Time (HRT) in the reactor was varied from $2,3,4$, and 5 days and the resulting COD outputs were $6783 \mathrm{mg} / \mathrm{L}, 6494 \mathrm{mg} / \mathrm{L}, 5806 \mathrm{mg} / \mathrm{L}$, and $4722 \mathrm{mg} / \mathrm{L}$ respectively. The results represented up to $38 \%$ in COD reduction. Biogas was produced from the UASB Reactor with the maximum production rate of 1.56 $\mathrm{mL} / \mathrm{min}$. The composition of the biogas was methane (56.4\% -mole), carbon dioxide $(42.7 \%$-mole), and impurities $(0.9 \%$-mole) with the Lower Heating Value (LHV) of $20.2 \mathrm{MJ} / \mathrm{Nm}^{3}$.
\end{abstract}

Keywords: Biogas, Citarum Harum, HRT, Tofu Wastewater, UASB Reactor.

\section{Introduction}

Indonesia has more than 84,000 units of tofu industries with production capacity of more than 2.56 million tons per year. Tofu liquid waste contains Chemical Oxygen Demand (COD) of 5000$8000 \mathrm{mg} / \mathrm{L}$ and Total Suspended Solid (TSS) of more than 1000 $\mathrm{mg} / \mathrm{L}$. For every $1 \mathrm{~kg}$ of soybeans processed into tofu, liquid waste can be produced up to 40-43 times larger (Indriyati and Susanto, 2012). Anaerobic decomposition is one of the alternatives to reduce COD and to produce biogas. In Indonesia, tofu industries are still disposing the untreated liquid wastes due to the relatively high processing costs. Waste treatments need to be improved to obtain affordable cost for tofu industries. Liquid wastes generated from the tofu industries around City of Bandung, West Java Province, ultimately end in Citarum River. The Government of Indonesia established Citarum Harum national program as one of the efforts to clean Citarum River, by reducing the wastewater disposal to the river.

The high capital cost of anaerobic tofu liquid waste treatment is caused by high reactor volume needed for the treatment process. Upflow Anaerobic Sludge Blanket (UASB) reactor could be used for the anaerobic processing of tofu liquid waste into biogas with the amount of $0.13 \mathrm{~L} / \mathrm{g}$ COD with the retention time of 4 days. In a regular process, it requires a minimum of 12 days to remove $95 \%$ of the COD to reach the COD of $300 \mathrm{mg} / \mathrm{L}$ (Wagiman, 2007). Thus, retention time with wider range has to be investigated. The purpose of this research was to determine the Hydraulic Retention Time (HRT) using UASB reactor for COD reduction and biogas production.

\section{Experimental Procedures}

Tofu liquid waste was obtained from a tofu producer in City of Bandung, as a by-product of tofu clotting process. The characteristics of the tofu liquid waste are listed in Table 1.

\begin{tabular}{llll}
\multicolumn{4}{c}{ Table 1: Characteristics of tofu liquid waste } \\
\hline No & Parameters & Value & Unit \\
\hline 1 & COD & 7,619 & $\mathrm{mg} / \mathrm{L}$ \\
2 & TSS & 1,035 & $\mathrm{mg} / \mathrm{L}$ \\
3 & pH & 4 & - \\
\hline
\end{tabular}

The UASB reactor was made from polyvinyl chloride (PVC), with the operational liquid capacity of $33.7 \mathrm{~L}$, as seen in Figure 1. Tofu liquid waste was introduced into the reactor, with a fed batch system, every 24 hours, through the Feed Inlet (I). The Hydraulic Retention Time (HRT) of the liquid inside the reactor was varied from $2,3,4$, and 5 days.

Liquid samples were withdrawn from the Effluent Valve (E) for COD concentration measurements using UV-VIS Spectrophotometric method (wavelength $420 \mathrm{~nm}$ ). In compliance with the Indonesian SNI Standard Number 06-6989.2-2004, the liquid samples were diluted 50 times for COD measurements. The liquid TSS was measured using Indonesian SNI Standard Number 066989.3-2004. The liquid $\mathrm{pH}$ was determined using $\mathrm{pH}$ test paper. The biogas was withdrawn from Gas Valve (B) and the biogas production was measured using a graduated cylinder, filled with water inside a beaker glass. The duration of measurements was 15 minutes and the volume changes of the water column were recorded. The compositions of biogas were analyzed using a Gas Chromatography (Model Shimadzu GC-2014) equipped with a Thermal Conductivity Detector (TCD). The Lower Heating Value (LHV) of the biogas was calculated by averaging the calorific values of the gas components. 


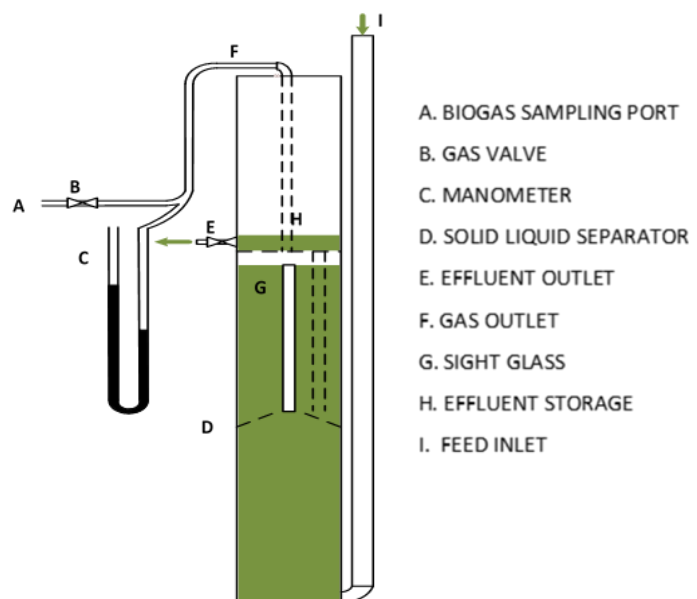

Fig. 1: Upflow Anaerobic Sludge Blanket (UASB) Reactor

\section{Result and Discussion}

\subsection{Effect of HRT on Biogas Production Rate}

For different sets of Hydraulic Retention Times, the biogas production rates were measured every 15 minutes. The results are shown in Figure 2.

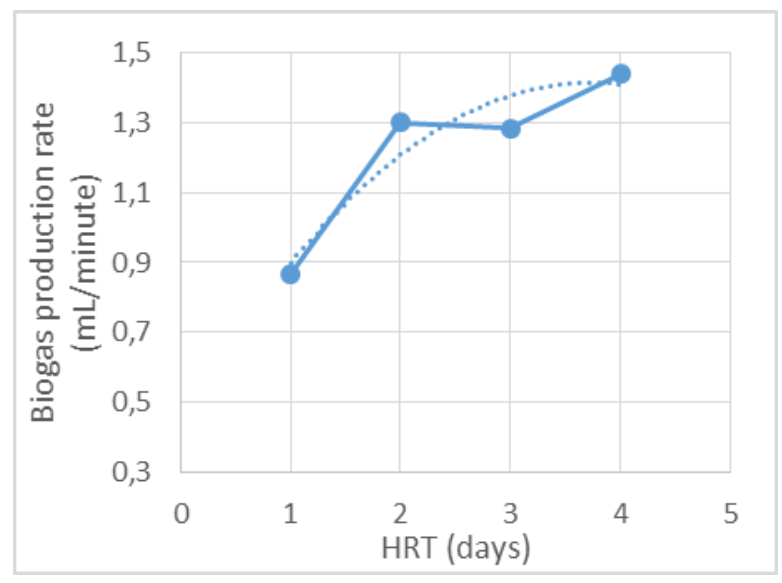

Fig. 2: Daily production rates of biogas with HRT of 4 days

The production rates of the biogas showed higher value every day. However, on the last day of the HRT, gas production showed less significant change and started to enter equilibrium. This indicated that the cycle from the HRT variation of 4 days had been completed and ready for the characterization and measurement of the biogas production rate. Therefore, data distribution of the biogas production rate on the last day of each HRT variations was conducted to see the effect of HRT on biogas production rate. The result showed in Figure 3.

The biogas production rate on the variations of HRT $2,3,4$, and 5 days respectively were $0.69,1.33,1.44$, and $1.56 \mathrm{~mL} / \mathrm{min}$. Figure 2 shows that the biogas production rate increased as the HRT increased from 2 days to 5 days. This phenomenon happened because in the low HRT, methanogenic microorganisms flushed out before reaching the maximum productivity. To avoid microorganism flushing, Deublein et al (2010) suggested that the HRT is adjusted between the ranges of 10-15 days. However, Wagiman (2007) reported that biogas production rate in a UASB batch system with the retention time 2,3 , and 4 days were $2.0,0.7$, and 0.4 $\mathrm{mL} / \mathrm{min}$ respectively. The decrease of biogas production was because the organic contents from feed in batch system from day to day would start to reduce as there were not feeding inlet and flush out effect by the feed as in the intermittent feeding system.

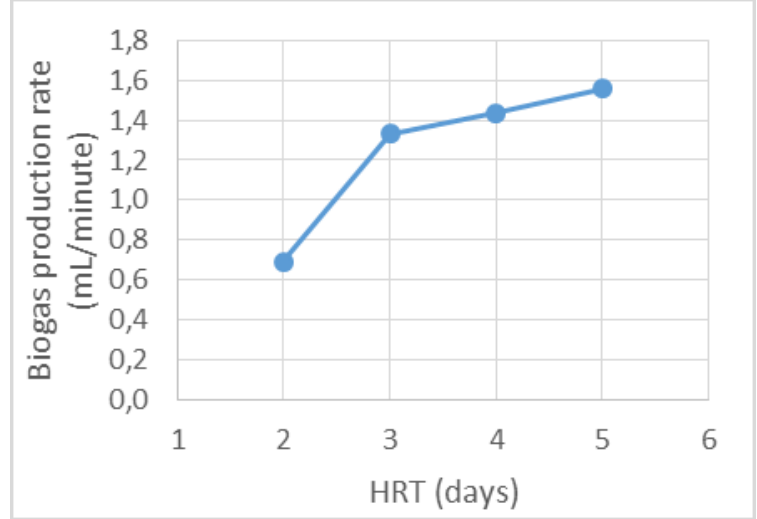

Fig. 3: Biogas production rate on the last day of each HRT variations

Biogas production which is relatively similar to the bigger operation capacity of the reactor to the research by Wagiman (2007) indicated that biogas production was still not optimum. The reactor output in Wagiman's research (2007) had a $\mathrm{pH}$ value 7. This indicates that in neutral $\mathrm{pH}$, biogas production would be better. Sorathia et al. (2012) reported that the ideal $\mathrm{pH}$ for anaerobic process, especially for methane formation is between $7-8$. Therefore, it was necessary to increase the $\mathrm{pH}$ of the reactor feed in order to increase the biogas production.

\subsection{Effect of HRT on Decomposition of Organic Con- tents}

COD concentration in each of the HRT variation and initial feed (considered as HRT 0 day), was measured to observe the reduction of organic contents. COD concentration in each HRT variation is shown in Figure 4. COD concentration in feed, HRT samples of 2, 3, 4, and 5 days respectively were $7,619 \mathrm{mg} / \mathrm{L}, 6,783$ $\mathrm{mg} / \mathrm{L}, 6,493 \mathrm{mg} / \mathrm{L}, 5,806 \mathrm{mg} / \mathrm{L}$, and $4,721 \mathrm{mg} / \mathrm{L}$. The calculation of COD reduction percentage is done by data in Figure 4. The results are shown in Figure 5.

COD reduction in HRT 2, 3, 4, and 5 days respectively were $11.0 \%, 14.8 \%, 23.8 \%$, and $38.0 \%$. Therefore, it could be reported that in the range of HRT in this research, COD reduction always increased proportional to HRT. Research conducted by Wagiman (2007) reported COD reduction reached $85 \%$ on day 4 . The considerable difference was due to the process done by Wagiman using batch feeding system so that the waste had longer retention time in the reactor and the decomposition of organic content lasted longer without any effect of flushed out by feeding inlet.

From the biogas production data, it was found that the volume of biogas produced per unit mass of reduced COD had an average value of $0.12 \mathrm{~L} / \mathrm{g}$ COD reduction. The value was relatively similar from the results of Wagiman (2007), where it showed biogas production of $0.13 \mathrm{~L} / \mathrm{g}$ COD reduction. However, this value is still lower than the result by Oktiana et al. (2015) which used the feed of mixed green algae Ulva $s p$. with water (ratio 1:2) and produced biogas $0,33 \mathrm{~L} / \mathrm{g}$ COD reduction. The feedstock had $\mathrm{C} / \mathrm{N}$ ratio of 20.46. Sorathia et al. (2012) reported that the feedstock was good for anaerobic decomposition. Tofu liquid waste had $\mathrm{C} / \mathrm{N}$ ratio of 5.19 (Rahmat et al, 2014). Therefore, biogas production rate per unit mass of COD reduced from tofu liquid waste could be increased by mixing it with other organic wastes with high $\mathrm{C} / \mathrm{N}$ ratio. The composition of biogas was analyzed with gas chromatography. The biogas composition is summarized in Table 2. The results of biogas characteristics were in accordance with the general characteristics of biogas. The biogas had two main components, methane and carbon dioxide with fewer impurities (Deublein et al., 2010). The impurities were still not identified, in the form of hydrogen, nitrogen, and hydrogen sulfide. Based on the composition, the lower heating value of biogas was $20.2 \mathrm{MJ} / \mathrm{Nm} 3$. 


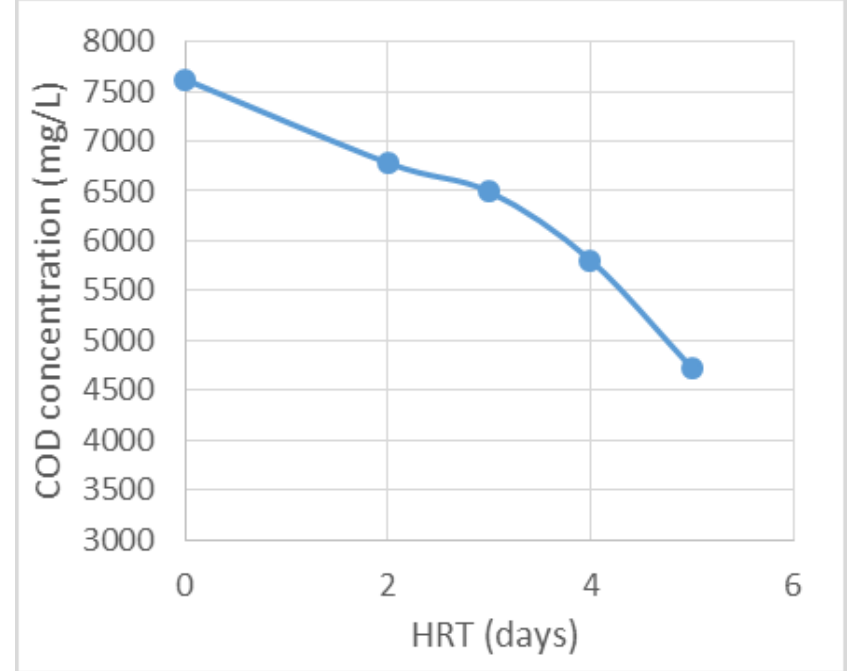

Fig. 4: COD concentration in output samples of each HRT variations

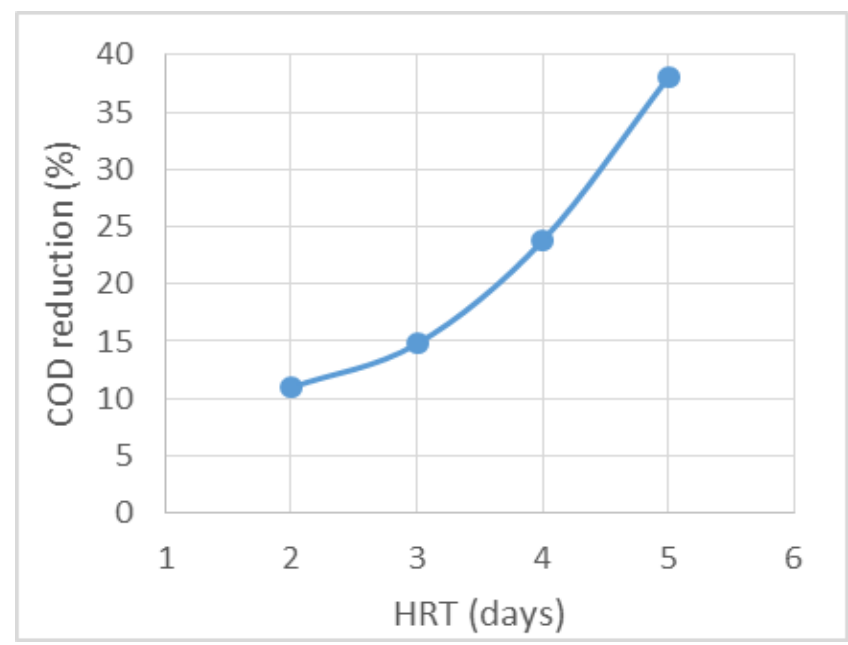

Fig. 5: COD reduction of each HRT variations

Table 2: Biogas composition

\begin{tabular}{cc}
\hline Composition & Concentration (\%-mole) \\
\hline Methane & 56.4 \\
Carbon dioxide & 42.7 \\
Impurities & 0.9 \\
\hline
\end{tabular}

\section{Conclusion}

The anaerobic decomposition process conducted by using UASB reactor with tofu liquid waste as feedstock had initial COD concentration of 7,619 mg/L, pH 4, and TSS 1,035 mg/L. Biogas production rates with the liquid HRT of $2,3,4$, and 5 days were $0.69,1.33,1.44,1.56 \mathrm{~mL} / \mathrm{min}$ respectively. The composition of biogas was methane (56.4\% -mole), carbon dioxide ( $42.7 \%$-mole), and impurities ( $0.9 \%$-mole) with the Lower Heating Value (LHV) of $20.2 \mathrm{MJ} / \mathrm{Nm}^{3}$. The liquid effluent COD concentration with the liquid HRT of 2, 3, 4, and 5 days were 6,$783 ; 6,493 ; 5,806$; and $4,721 \mathrm{mg} / \mathrm{L}$, representing COD reduction of $11.0,14.8,23.8$, and $38.0 \%$-mass.

\section{Acknowledgement}

We acknowledge the gracious assistance from Andrias Wiji, the owner of PT. Cipta Tani Lestari, for his continuous support on the UASB reactor design.

\section{References}

[1] Deublein, D. and Steinhauser, A. "Biogas from waste and renewable resources. ” 2nd Ed., Wiley-VCH Verlag GmbH \& Co., Weinheim, 2010.

[2] Herout M., Malatak, J., Kucera, L., and Dlabaja,T. "Biogas composition depending on the type of plant biomass used." Czech University of Life Sciences Prague, Res. Agr. Eng. Vol. 57 (2011) No.4: 137-143.

[3] Indriyati dan Susanto, J.P. "Biological processing performance of tofu liquid wastes". Jurnal Teknologi Lingkungan Volume 13 (2012) No.2, 159-166. ISSN: 1441-318X (in Indonesian)

[4] Oktiana, T.D., Santoso, J., and Kawaroe, M. "Green Algae (Ulva Sp.) as feedstock for biogas production." Jurnal Ilmu dan Teknologi Kelautan Tropis, Vol. 7 (2015), No. 1, 191-203 (in Indonesian)

[5] Rahmat, Budy, Tedy Hartoyo, dan Yaya Sunarya. 2014. "Biogas production from tofu liquid waste on treated agricultural wastes." American Journal of Agricultural and Biological Sciences. 9 (2): 226-231. ISSN: 1557-4989.

[6] Sorathia, Harilal S.; Dr. Pravin P. Rathod; Arvind S. Sorathiya. 2012. "Biogas generation and factors affecting the biogas generation." Gujarat IJAET E-ISSN 0976-3945.

[7] Wagiman. "Biogas production from tofu liquid wastes using Upflow Anaerobic Sludge Blanket (UASB) Reactors." UGM Bioteknologi 4 (2007) No.2: 41-45, ISSN: 0216-6887, DOI:10.13057 (in Indonesian) 